UDC 614.447.6-027.45-004.413.4 (4) (476)

DOI: $10.21668 /$ health.risk/2017.4.01.eng

\title{
ANALYSIS OF LEGAL AND METHODOLOGICAL GROUNDS FOR RISK-ORIENTED SURVEILLANCE OVER CONSUMER PRODUCTS: TASKS AND DEVELOPMENT PROSPECTS IN THE EURASIAN ECONOMIC UNION*
}

\author{
N.V. Zaitseva ${ }^{1}$, I.V. May ${ }^{1}$, S.I. Sychik ${ }^{2}$, E.V. Fedorenko ${ }^{2}$, L.M. Shevchuk ${ }^{2}$ \\ ${ }^{1}$ Federal Scientific Center for Medical and Preventive Health Risk Management Technologies, 82 Monastyrskaya \\ Str., Perm, 614045, Russian Federation \\ ${ }^{2}$ Scientific-practical Hygiene Center, 8 Akademicheskaya Str., Minsk, 220012, Republic of Belarus
}

The paper dwells on basic legal and sub-legislative documents issued in the EU, the USA, Canada, by the WTO and Codex Alimentarius Commission which provide control of consumer products safety on the basis of assessing risks for consumers' life and health. Risk-oriented surveillance is shown as a system which makes for lower loads on business but still provides systemic control over most hazardous products. The EU legislation fixes the right to perform supranational control over state control systems existing in the EU member states in terms of their relevance and legitimacy. This supranational control is supported by organizational structures and regulatory and methodological documents. National control systems are systematically reviewed and analyzed in order to secure their conformity to supranational regulatory acts, to detect any cases of noncompliance, and to spread the best practices. Risk analysis reviews and results are open and discussable. As a result of products hazards assessment their turnover can be limited, or they can be withdrawn from the market, or additional information on hazards or risks they may cause is to be provided for consumers. Public and constantly operating systems of informing about hazardous goods are well-developed. International experience and practices in the sphere of risk-oriented surveillance over consumer products can be and should be applied in the Eurasian Economic Union (EEU) countries.

The Eurasian Economic Union countries fix orientation at observing consumer goods safety principles in their legislation. There are also legal grounds for and practices in the sphere of risk-oriented approach to products manufactures. But it is necessary to further develop a products classification system as per consumer health risk parameters. And this task requires working out unified approaches to classification of both eatable and non-eatable products. It seems relevant to develop a public analytical database of risk-oriented control created with the use of the control and surveillance activities results obtained in the EEU countries. All the involved parties should more actively interact and exchange information on issues of products risks assessment as it is a vital component required for further development of the system.

Key words: consumer products, products risks assessment, risk-oriented surveillance, legislative basis, methodological approaches.

(C) Zaitseva N.V., May I.V., Sychik S.I., Fedorenko E.V., Shevchuk L.M., 2017

Nina V. Zaitseva - Academician of the Russian Academy of Sciences, Doctor of Medicine, Professor, Director (e-mail: znv@,fcrisk.ru; tel.: +7 (342) 237-25-34).

Irina V. May - Doctor of Biological Sciences, Professor, Deputy Director for Research (e-mail: may@fcrisk.ru; tel.: +7 (342) 237-25-47).

Sergei I. Sychik - Candidate of Medicine, Associate Professor, Director (e-mail: rspch@rspch.by; tel. +375 (17) 28-413-70).

Ekaterina V. Fedorenko - Candidate of Medicine, Associate Professor, Deputy Director for practical and sanitary-epidemiological supervision and work with EEC (e-mail: afedorenko71@mail.ru; tel. +375 (17) 28-41365).

Larisa M. Shevchuk - Candidate of Medical Sciences, Associate Professor, Deputy Director for Research (email: SheuchukLM@mail.ru; tel. +375 (17) 29-250-15).

* The research was performed duevti funancial support by EEC within the research work No H-17/197 
Creation of the Eurasian Economic Union (EAEU) and formation of the Single Economic Space presuppose the elimination of unnecessary state barriers that hamper free trade in the territories of the Union member countries. Economic integration is the leading motive of the Eurasian project, its main driving force [11]. To date, the sales turnover between the EAEU member states amounts to more than 43 billion US dollars $(14.2 \%$ of the total trade volume of the EAEU countries) ${ }^{1}$. The share of consumer goods in 2016 amounted to about $25.7 \%$ in value terms (food products: 13.0\%, non-food: $12.7 \%)$. Based on mutual trade, products of animal and vegetable origin (meat, fish, meat products, meat by-products, vegetables, fruits, cereals, products of flour-andcereals industry) come to the common market; fats and oils of vegetable and animal origin; sugar and confectionery; alcoholic and non-alcoholic beverages; soaps, detergents; perfumery and cosmetics; fabrics, carpets, clothes, shoes, toys, furniture, etc.

At the same time, we gained facts that testify to the cases of harm to consumers' health due to unsafe products traded on the market of the single economic space $[5-7,10,12]$. Since public health protection is the priority of any EAEU member state, development of the fundamentally new approaches to control safety of the consumer products, when circulating in the market, and to assessing their compliance with the legally established sanitary and epidemiological requirements, seems relevant.

For the Eurasian Economic Union, where state surveillance systems in the context of sanitary and epidemiological wellbeing are independent ${ }^{2}$, the elaboration of common methodological approaches to developing, approving, modifying and applying the common sanitaryepidemiological and hygienic requirements for products, as well as to products control procedure and the selection of adequate measures of state regulation (coercion), is an extremely urgent task $[1,9]$. The solutions for such a problem would allow, with an improvement in overall product safety, to minimize contradictions and misunderstandings in assessing the results of control and surveillance activities by national regulators regarding products traded on the market of EAEU.

The EAEU basic documents consider products safety as "the absence of unacceptable risk associated with the potential of causing harm and (or) damage" ${ }^{3}$. The documents provisions require the subordinate regulatory-methodological and informational grounds for assessing and managing the risks of potential harm to the protected values in relation to consumer products for assessing and managing risks for consumers' life and health and their property interests.

\footnotetext{
${ }^{1}$ On the results of foreign trade in goods of the Eurasian Economic Union. January - December 2016: analytical review of the Eurasian Economic Commission. Available at: http://www.eurasiancommission.org/ ru/act/integr_i_makroec/dep_stat/tradestat/analytics/Documents/Analytics_E_201612_180.pdf (28.08.2017).

${ }^{2}$ Treaty on the Eurasian Economic Union in the wording of 08.05 .2015 with amend. and alterations.ddt. 12.08.2017. Section X, Art. 51 "General principles of technical regulation". Available at: http://www.consultant.ru/document/cons

doc_LAW_163855/ef821de674bd00be353bb7b3efffdb453736d1f0/ (14.08.2017).

${ }^{3}$ Treaty on the Eurasian Economic Union in the wording of 08.05 .2015 with amend. and alterations.ddt. 12.08.2017. Appendix No. 9 "Protocol on technical regulation within the framework of the Eurasian Economic Union". Available at: http://www.consultant.ru/document/cons doc LAW 163855/d4a8ed9c96e6b5519b558f85f72112 ed06b1e527/ (12.08.2017).
} 
To date, all the EAEU member states legislatively ensured the transition to a risk-oriented state surveillance, and in particular, in the sphere of ensuring sanitary and epidemiological wellbeing and protection of consumers' rights. However, the implementation of models in most countries is in the stage of formation and accumulating data for assessing the efficiency and viability [3, 9]. In addition, the risk-oriented approaches in the organization of surveillance are meant to justify the frequency and scope of auditing legal entities and/or individual entrepreneurs' activities, rather than products as such already released onto the market.

Within this framework, an experience in the field of risk-oriented surveillance of products safety in the member states of the European Union, the United States, Canada, some individual Eurasian Economic Union member states and such international organizations as the World Trade Organization and Codex Alimentarius Commission, etc. seemed to be of exceptional interest.

The purpose of the study is to analyze the legal and methodological grounds for functioning the risk-oriented model of control and surveillance activities in the European Union, the United States, Canada and the EAEU countries in terms of ensuring products safety as the basis for improving the system for assessing health risks to the population from consumer products traded on the common market of the Eurasian Economic Union.

Materials and methods. In the course of the study, we reviewed over 150 regulatory and non-mandatory legal acts of the European Union, the USA and Canada, about 40 methodical documents of the Eu- ropean Union, the USA and Canada; about 30 normative and methodical acts of the EAEU member states (the Republic of Belarus, the Republic of Kazakhstan, the Republic of Kyrgyzstan, the Republic of Armenia, Russian Federation). Approximately 30 documents of international organizations, including the World Trade Organization (WTO), Codex Alimentarius Commission, the Organization for Economic Cooperation and Development (OECD), the International Organization for Standardization (ISO), the European Committee for Standardization, and other international regulators in the field of consumer products.

Results and discussion. The European Union (EuroUnion, EU) as a unique and complex organization, which unites 28 states, due to the longer history than the EAEU history, can be considered as an object for studying the experience in many areas of economy, including product safety.

The EU common goods market consolidates about 500 million consumers and 21 million manufacturers of different forms and sizes ${ }^{4}$. One of the union intentions is to ensure free goods flow on the market and establishing high standards for safety, including for in relation to consumers. The EU represents all its Member States in the World Trade Organization (WTO) and, having legal personality, can be a party to international agreements.

The Europe equivalent for the Russian "control and surveillance activities in the products market is "market surveillance" and official controls/surveillance for food, feedstuff, plants $[2,15]$. The peculiarity of the surveillance organizational structure over products on the Euro-Union market is the controls and surveillance at the EU

\footnotetext{
${ }^{4}$ About the EU . European Union. Available at: https://europa.eu/european-union/about-eu/countries en (06.08.2017).
} 
level, and simultaneously at the national level of the member states by the authorized member states authorities. Another tool for risk management is obliging the products manufacturers and other market participants to ensure and prove safety of products and to inform about possible threats.

Ensuring product safety in the EU is built on three key elements: legislation, quick response system, and standards.

The basic legislative documents that regulate ensuring safety of life and health for people using any type and category of products in the European Union are the Directive 2001/95/EC (of the European Parliament and the General Product Safety Council - General Product Safety Directive $^{5}$ ), which is elaborated in the context of developing the Directive 92/59 EEC under the same name, Regulation (EC) $765 / 2008^{6}$ ) (as applied to non-food products), Regulation (EC) 882/2004 $4^{7}$ ) and Regulation (EU) $2017 / 625^{8}$ ((in respect to foodstuffs, feed and plants). The same documents define the powers of the surveillance bodies with regard to products, their rights and duties.

The Directive on general safety of products 2001/95/EC establishes that "safe product shall mean any product which, under normal and reasonably foreseeable conditions..., does not present any risk or only the minimum risks ... considered to be acceptable" (Art. 2, para. b). Since risk is considered as a criterion of safety, Article 1 of the Directive establishes a general principle stating that "... legislation should be based on a risk analysis". It is determined that risk assessment is based on the scientific evidence available, and should be carried out based on independence, objectivity, transparency and follow the principle of preventive measures, providing for preventive risk management until "more comprehensive risk assessment".

The main responsibility for product safety lies with the operators of economic activities. However, "The Member States must ensure compliance with food laws, monitor and verify that the relevant requirements of food law are met by operators of economic activities in the production of food and feedstuff at all stages of production, processing and marketing" (Article 17 (2)).

The Directive authorizes national bodies to independently monitor the market and take actions against hazardous products through the designated national authorities.

The national authorities of the European Union countries that exercise monitoring and surveillance over the products market have the powers to control all products before and after their release; on

\footnotetext{
${ }^{5}$ General Product Safety. Directive (GPSD) 2001/95/EC. European Commission. Available at: https://ec.europa.eu/growth/single-market/european-standards/harmonised-standards/general-product-safety en (06.08.2017).

${ }^{6}$ Regulation (EC) No 765/2008 of the European Parliament and of the Council of 9 July 2008 setting out the requirements for accreditation and market surveillance relating to the marketing of products and repealing Regulation (EEC) No 339/93 (Text with EEA relevance). EUR-Lex: Access to European Union law. Available at: http://eurlex.europa.eu/legal-content/EN/TXT/?uri=CELEX:32008R0765 (06.08.2017).

${ }^{7}$ Regulation (EC) No 882/2004 of the European Parliament and of the Council of 29 April 2004 on official controls performed to ensure the verification of compliance with feed and food law, animal health and animal welfare rules. EUR-Lex: Access to European Union law. Available at: http://eur-lex.europa.eu/legalcontent/EN/ALL/?uri=CELEX\%3A32004R0882 (06.08.2017).

${ }^{8}$ REGULATIONS: Regulation (EU) 2017/625 of the European Parliament and of the Council of 15 March 2017. Official Journal of the European Union, 2017. Available at: http://eur-lex.europa.eu/legal-content/EN/TXT/PDF/?uri= CELEX:32017R0625\&from=EN (08.08.2017).
} 
the procedure for determining safety of any product, which may represent even minimal risks [13, 14, 16-18]. They check whether the goods available on the market are safe, ensure that the product safety laws and regulations are respected by manufacturers and other market participants, and apply sanctions when necessary.

It is extremely important that the Directive 2001/95/EC states that "conformity of a product with the criteria designed to ensure the general safety requirement shall not bar... from taking appropriate measures to impose restrictions on its being placed on the market, or to require its withdrawal from the market or recall where there is evidence that, despite such conformity, it is dangerous"(Art. 3, para. 5). Consequently, it is recognized that a situation where, in observance of all the requirements and standards, products under real conditions of use can be dangerous for life and health of a consumer.

Surveillance authorities warn potential consumers about dangerous products and encourage voluntary withdrawal of products from the market by their manufacturers, when they discover hidden risks.

The document accents to the importance of cooperation between the control bodies of the member states, including risk assessment, joint product auditing, exchange of competencies and scientific knowledge, implementation of joint projects for surveillance, tracing, withdrawal or recall of hazardous products. The European Commission (EC) as an executive body of the European Union is instructed to "promote and take part in the operation in a European network of the Member States authorities competent for product safety, in particular in the form of administrative cooperation" (Art. 10, para. 1).

It should be noted that the Directive 2001/95/EC, without establishing unambiguously the criteria for acceptable risk, operates with the notion of "serious risk", which refers to a risk requiring rapid intervention by public authorities, including those the effects of which are not immediate, requiring rapid intervention by the public authorities (para. d, Art. 2).

Adopted in April 2004, the EU Regulation No. $882 / 2004^{9}$ on the official control of compliance with the legislation in the field of food and feedstuffs established for the first time a risk-oriented approach to control, and Regulation 2017/625) ${ }^{10}$ broadened the application thereof [18]. The documents establish:

- the risk-oriented approach assumes that the load on business representatives is minimized, the control focuses on high-risk objects. When planning monitoring activities, reports on past audits of the objects under surveillance should be taken into account. In doing so, the competent authorities, in carrying out control activities and revising their periodicity, should consider the likelihood that consumers may be misled about the properties, quality, composition or country of origin of the products they purchase;

- transparency of official control is focused on increasing the responsibility of the surveillance authorities. The document provides for the possibility to publish the control results and establish ratings;

\footnotetext{
${ }^{9}$ Legislation on official controls. European Commission: Food. Available at: https://ec.europa.eu/food/safety/official_controls/legislation_en (05.09.2017).

${ }^{10}$ REGULATIONS: Regulation (EU) 2017/625 of the European Parliament and of the Council of 15 March 2017. Official Journal of the European Union, 2017. Available at: http://eur-lex.europa.eu/legal-content/EN/TXT/PDF/ ?uri=CELEX:32017R0625\&from=EN (08.08.2017).
} 
- foundation of reference laboratories and centers in those sectors where there is a need to create uniform, comparable methods for analysis, testing and diagnostics;

- explanation of selection, analysis, testing, interpretation of results implies close interaction between supervising and supervised organizations in order to explain to the auditees the methods of sampling, analysis, testing, diagnosis and interpretation of the results obtained.

The European Commission ensures the development and control over the observance of clear and uniform rules applicable to food and non-food products. Its tasks are to facilitate infrastructure, organization, legal authority, etc. to be proper enough to ensure market surveillance in compliance with the law, in order to improve, including simplification, market surveillance procedures and product control in the EU and at its borders; to develop tools for coordinating the activities of national surveillance bodies (for example, discussion forums, databases and general market surveillance campaigns).

Another objective of the European Commission is to promote the implementation of the market surveillance structure and to ensure its effectiveness at national levels.

A special condition for the successful operation of product safety control and rapid response to risks, the EU documents determine the availability of rapid warning systems. There are several such systems in the European Union: Rapid Exchange of Information System (RAPEX), Rapid Alert System for Food and Feed (RASFF), Trade Control and Expert System (TRACES) and several others.

For example, RAPEX computer system is designed for rapid exchange of information between the member states and the European Commission on serious nonfood products risks for consumers (except for drugs, chemicals and medical equipment). The system accumulates data on hazardous products, on risk assessment, on control tests methods and their results, on other aspects that should be taken into account in monitoring activities, sharing knowledge and best practices. In addition to the above, the information that enables identifying products, the nature and duration of measures or actions taken is subject to disclosure.

This is an intensively developing system. For instance, since China is the largest source of imports of goods to the EU today, the European Union in collaboration with General Administration of Quality Supervision, Inspection and Quarantine of the People's Republic of China-AQSIQ) establishes RAPEX-China system for the exchange of information between the European Commission and AQSIQ on dangerous consumer goods of Chinese origin found in the EU. Bilateral cooperation with AQSIQ is complemented by tripartite cooperation with the U.S. Consumer Product Safety Commission involved.

Rapid Alert System for Food and Feed (RASFF) ensures rapid interaction between the national authorities of the EU member states responsible for food safety, which enables the authorities to promptly arrange withdrawal of unsafe food ${ }^{11}$. It is legally enshrined that the system should work twenty four - seven days a week ${ }^{12}$.

All EU member states submit reports to the European Commission with an assessment of market surveillance activities (by market sector), which allows for annual generalized analysis of effectiveness for system functioning and to justify measures to improve it [19].

In the United States, a country where the risk assessment methodology was implemented in legislation earlier than in other countries, a safety as "the absence of un- 
acceptable risk to life and health ..." is defined in the US Consumer Product Safety Improvement Act No. 4040, of $2008^{13}$ ).

The product safety issues based on risk assessment are governed by the National Technology Transfer and Advancement Act, 15 U.S.A. $\$ 3701$ et seq., 1996) ${ }^{14}$ and the Risk Assessment and Cost Benefit Act (RACBA), ddt. 23.02.1995 H.R. 1022 104$e p)^{15}$.

The Code of Federal Regulations of the USA contains legislative acts providing for the assessment of risks of food, cosmetic, chemical and other products, including the most sensitive groups, to the population health $^{16,17,18}$. Thus, the law on safety of food, drugs and cosmetics ${ }^{19}$ foresees health risk assessment, including the diseases associated with the mentioned goods in the process of their production and circulation on the market, as well as the establishment of quality standards based on risk assessment.

Compliance with standards is ensured by strict liabilities of producers, standardization and certification bodies. In addition to administrative penalties and damages caused by poor-quality goods, manufacturers can be enforced with punitive damages, aimed at preventing future violations, by court of law in favor of state's revenue. And the amount of such losses reaches hundreds of million dollars (for example, Snyder vs. American Association of Blood Banks precedent, in which the patient recovered \$11 million from the Association for contracting AIDS as a result of blood transfusions, which was tested in the laboratory of the Association [21]). The standardization and certification bodies that allowed low-quality products release into circulation may also be held liable for negligence and inadvertence.

In general, the US laws minimize legislative pressure on producers, makes a significant emphasis on informing the public at large, business communities and consumers about the risks of products, thereby guiding manufacturers to voluntarily assess and minimize product risks for the population life and health. At the same time, legislation fixes as a priority the system for controlling products safety at all stages of production as a guarantee for safety of

\footnotetext{
${ }^{11}$ Regulation (EC) No 178/2002 of the European Parliament and of the Council of 28 January 2002 laying down the general principles and requirements of food law, establishing the European Food Safety. Authority and laying down procedures in matters of food safety. EUR-Lex: Access to European Union law. Available at: http://eur-lex.europa.eu/legalcontent/EN/TXT/?uri=celex:32002R0178 (06.08.2017).

${ }^{12}$ Commission Regulation (EU) No 16/2011 of 10 January 2011: Laying down implementing measures for the Rapid alert system for food and feed. Official Journal ofthe European Communities, 2011. Available at: http://eurlex.europa.eu/legal-content/EN/TXT/PDF/?uri=OJ:L:2011:006:FULL\&from=EN (06.08.2017).

${ }^{13}$ Consumer Product Safety Improvement Act of 2008: Public Law 110-314, 110th Congress, 2008. Available at: https://www.cpsc.gov/s3fs-public/cpsia.pdf (06.08.2017).

${ }^{14}$ National Technology Transfer and Advancement Act of 1995: Public Law 104-113, 104th Congress, 1996 Available at: https://www.nist.gov/standardsgov/national-technology-transfer-and-advancement-act-1995 (06.08.2017).

${ }^{15}$ H.R.1022 - Risk Assessment and Cost-Benefit Act of 1995:/ 104th Congress (1995-1996). Congress.Gov. Available at: https://www.congress.gov/bill/104th-congress/house-bill/1022 (06.08.2017).

${ }^{16}$ Federal Food, Drug, and Cosmetic Act (FD\&C Act). U.S.Food and drug. Available at: https://www.fda.gov/RegulatoryInformation/LawsEnforcedbyFDA/FederalFoodDrugandCosmeticActFDCAct/ default.htm (06.08.2017).

${ }^{17}$ Toxic Substance Control Act (TSCA): Public Law 94-469, 94th U.S. Congress, 1976. Available at: https://www.govtrack.us/congress/bills/94/s3149/text/enr (дата обращения: 06.08.2017).

${ }^{18}$ Federal Hazardous Substances Act (Codified at 15 U.S.C. §§1261-1278), 2011. Available at: https://www.cpsc.gov/s3fs-public/fhsa.pdf (06.08.2017).

${ }^{19}$ CFR - Code of Federal Regulations. Title 21. Food and drugs chapter I - food and drug administration department of health and human services subchapter A. U.S. Food and Drug. Available at: https://www.accessdata.fda.gov/scripts/cdrh/cfdocs/cfCFR/CFRSearch.cfm?CFRPart=7\&showFR=1 (07.09.2017).
} 
goods at the "exit". And for children's toys, food and chemicals, there are mandatory requirements for compulsory risk assessment for life and health of consumers and risks reduction to acceptable levels.

The notion of a "significant risk" is used in the US regulatory framework. Three classes of risk "significance" (classes A, B, C) are based on two components: the severity of damage/illness and the likelihood of this damage occurrence. For example, the risk refers to " $\mathrm{A}$ " class if causing death or serious harm (illness) is probable or very likely; to "B"class, if the probability of death or serious harm is low, etc. The hazard assessment takes into account the following factors (but is not limited to):

- actually recorded cases of diseases or injuries associated with the use of a product;

- a product hazard assessment results for different population segments that will be exposed to the product in question, including the most sensitive groups;

- an assessment of the severity of potential harm to the health of populations at risk;

- an assessment of hazard occurrence probability;

- an assessment of immediate or delayed consequences of risk occurrence.

Based on the above factors analysis, surveillance authorities classify products into three classes ${ }^{19}$ with the aim of justifying the decisions on managing risks to consumers' health (Table 1).

For example, based upon results of assessing risks to children life and health, the US Consumer Product Safety Commission banned the sales of Neocub toys (mainly known in the US as Buckyballs or Nanodots).

In the United States, the cumulation of data on products non-compliance with the requirements of laws on safety is
Table 1

Classification of products to be withdrawn from the market taking into account level of hazard (risk) for the health of consumers

\begin{tabular}{|l|l|}
\hline Class & \multicolumn{1}{|c|}{ Explanation } \\
\hline Class A & $\begin{array}{l}\text { Products that are in violation of safety re- } \\
\text { quirements, when used, or when in contact } \\
\text { with, there is a likelihood of serious ad- } \\
\text { verse consequences for health or death of a } \\
\text { consumer. } \\
\text { Probable actions: withdrawal from the } \\
\text { market, products recall from purchasers }\end{array}$ \\
\hline Class B & $\begin{array}{l}\text { Products in violation of safety require- } \\
\text { ments, when used or when in contact with, } \\
\text { there is a likelihood of developing tempo- } \\
\text { rary or reversible long-term consequences } \\
\text { for consumers health, or a likelihood of } \\
\text { serious adverse health effects is remote. } \\
\text { Actions: withdrawal from the market }\end{array}$ \\
\hline Class C & $\begin{array}{l}\text { Products with safety breaches, when used } \\
\text { or when in contact with, there is a likeli- } \\
\text { hood of adverse effects on consumers' } \\
\text { health is minimal. } \\
\text { Actions: restriction of market release }\end{array}$ \\
\hline
\end{tabular}

mandatory. Since 2013, the updates on the project on implementing the methodology for assessing risks of imported consumer products are being accumulated. The program allows CPSC employees to analyze data provided by the US Customs Service and the Border Guard, and determine highrisk shipments of consumer goods entering the US ports and then to make reasonable and effective decisions on the selection of goods needed for verification. [20] In addition, such a program also allows you to recognize products of low risk level, but shipped together with consignments of high-risk products and prevent blocking low-risk products arrivals to the US market.

The specific experience in the riskoriented surveillance of consumer products safety was gained in Canada.

The system of state control over consumer goods safety in Canada is built upon 
principles of the priority to post-market approach. For manufacturers and sellers, there is no prior approval of the products safety authorities required to release products into market circulation. Under the Consumer Product Safety Act of Canada ${ }^{20}$, manufacturers are fully responsible for the fact that the consumer products they manufacture, import, sell or advertise in Canada do not pose a threat to human health or safety. In this case, according to the Art. 21-22 of the Act, a person authorized for surveillance activities over products safety at any appropriate time may exercise control in places, including transport, where a consumer product is manufactured, imported, packaged, stored, advertised, sold, labeled, inspected or transported.

State, through the creation of a specific Consumer Product Safety Program, concentrates its resources on controlling those types of products where the risks to consumers' health are high. The sources of information for risk assessment of products in operation of this program are the reports on incidents related to products from manufacturers or consumers; reports (e.g. on products recalls) of other countries, research results, information from health and safety professionals, mass media and other sources.

There are considered such factors, as

- how serious is the actual or potential harm to consumer health is?;

- is it prudent to attribute the damage, if any, to the use of a product?

- whether there were other incidents related to a product?;

- what is the age of a consumer whose health is damaged?
- whether a consumer was aware of the potential hazard?;

- whether a product that caused harm to health was new or already in use?;

- whether a product represented potential hazard to consumer health or likelihood of fatal outcome when it is used normally?;

- is a realization of harm to consumers health when using a product for other purposes ... etc. possible?

A risk in full compliance with the classical methodical approaches is measured by combining the severity of harm that a consumer product can cause with the likelihood of this harm occurrence. The severity of damage is determined using the scale of five levels: 1) insignificant, 2) moderate, 3) severe, 4) life threatening and 5) fatal. The probability of harm to the product user is determined using the scale of six levels: 1) extremely rare, 2) rare, 3) unusual, 4) random, 5) ordinary and 6) frequent.

The level of product risk is determined using a matrix that combines the severity of injury and its probability. Risk levels are defined as "very high", "high", "medium" and "low".

The risk profile allows you to determine the overall level of risk (very high, high, medium, low) for a consumer product or cosmetics.

The TBT Agreement and the Agreement on the Application of Sanitary and Phytosanitary Measures (SPS measures) have been adopted to ensure fair trade and safety of products traded on the market of the World Trade Organization member countries. The SPS Agreement regulates food trade issues, while the TBT Agree-

${ }^{20}$ Canada Consumer Product Safety Act (CCPSA). Government of Canada. Available at: https://www.canada.ca/en/health-canada/services/consumer-product-safety/legislation-guidelines/acts-regulations/canadaconsumer-product-safety-act.html (07.09.2017). 
ment covers all non-food items.

In the international context, sanitary measures include legislation covering all stages of food products life cycle (sampling, requirements for final product, packaging and labeling, directly aimed at ensuring food safety, etc.), requirements for inspection procedures and approval (i.e. for surveillance), as well as risk assessment methods ${ }^{21}$.

The main principles of SPS Agreement are the harmonization and scientific validity of the applied sanitary measures. Harmonization assumes the widest possible use of Codex Alimentarius Commission standards, as defined in Art. 3.1 of the Agreement. In the absence of such, and also if the sanitary measure is more rigid in comparison with the documents requirements of the said international organization, it should be based on the appropriate scientific justification (Article 3.3). The requirements for food products, consistent with the standards and recommendations of Codex Alimentarius Commission, without additional justification, are adopted as being in accordance with the provisions of the WTO Agreement on SPS measures (Article 3.2).

When implementing the WTO Agreement on SPS measures, the states ensure that sanitary measures (and, as it follows from the definition, surveillance over product when it is marketed, also refers to such) are based on human life or health risks assessment relevant to circumstances. At the same time, the risk assessment methods developed by the relevant international organizations, i.e. Codex Alimen- tarius Commission, should be used (Art. 5.1).

In cases where relevant scientific evidence is insufficient, a Member may provisionally adopt sanitary or phytosanitary measures on the basis of available pertinent information, including that from the relevant international organizations as well as from sanitary or phytosanitary measures applied by other Members (Article 5.7).

The basic element of protecting consumer health is an appropriate level of sanitary protection (Appropriate level of protection - ALOP). In fact, the appropriate level of protection is equivalent to the notion of "acceptable risk" (Annex A.5). According to international approaches, the appropriate level of sanitary protection associated with food safety is customary understood as an existing or forecasted number of diseases due to foodstuff contaminated with dangerous chemicals or biological agents. Achieving and maintaining the level of acceptable risk requires introduction and implementation of the integrated interagency activities aimed at managing hazards associated with food. It should be noted that market surveillance, including listing of priority products and consistence of control, is one of the tools to ensure sanitary and epidemic wellbeing of the population.

Upon accession to the WTO, both the Russian Federation and the Republic of Kazakhstan declared that sanitary measures would be scientifically justified using risk assessment with the international standards applied ${ }^{22,23}$.

\footnotetext{
${ }^{21}$ Agreement on the Application of Sanitary and Phytosanitary Measures. World Trade Organization. Available at: www.wto.org/english/docs e/legal e/15sps 01 e.htm (20.08.2017).

${ }^{22}$ Report of the Working Party on the Accession of the Russian Federation to the World Trade Organization. Available at: http://economy.gov.ru/minec/activity/sections/foreigneconomicactivity/wto/doc20120201 0017 (06.09.2017).

${ }_{23}$ Report of the Working Party on the Accession of the Republic of Kazakhstan to the World Trade Organization.Available at: http://online.zakon.kz/m/Document/?doc id=35955627 (25.08.2017).
} 
The TBT Agreement ${ }^{24}$, which regulates, among other things, the general approaches to ensuring safety of non-food products, determines that technical regulations should be developed, adopted and applied only to fulfill a legitimate objective - national safety requirements, prevention of deceptive practices, protection of human health or safety, animals or plant life or health, or the environment. At the same time, risks that would arise when such goals are not achieved should be taken into account. When assessing such risks, such factors as available scientific and technical information, related processing technology, or intended end-uses of products, etc. are taken into account (Article 2.2).

When carrying out the conformity assessment procedures, it is necessary to strive to obtain adequate confidence that products conform with the applicable technical regulations, or standards, taking into account the risks non-conformity would create (Article 5.1.2).

The above-mentioned further confirms relevance of justifying the principles of state market surveillance for products that are common to the state members of the EAEU on the basis of health risk assessment.

Within the framework of the WTO Council for Trade in Goods, the Committee on Sanitary and Phytosanitary Measures operates, which is responsible for all matters governed by the "SPS Agreement" (paragraphs 1 and 4 of the Article 12, "SPS-Measures Agreement"), including the development of a procedure to monitor the process of international harmonization and coordination of such ac- tivity with relevant international organizations.

The Codex Alimentarius Commission ensures the development of food standards using risk assessment methodology, in collaboration with the $\mathrm{WHO}$ - the procedures for a risk-based approach to controlling imported food products and risk management. Thus, the Codex Alimentarius Commission developed the fundamental documents for the assessment of product risk: Working principles for risk analysis for food safety for application by governments $\mathrm{CAC} / \mathrm{GL}$ 62-2007, Principles and guidelines for the conduct of microbiological risk assessment CAC/GL-30, Principles and guidelines for the conduct of microbiological risk management (MRM) CAC/GL 63-2007, Guidelines for risk analysis of foodborne antimicrobial resistance CAC/GL 77-2011, Guidelines for the design and implementation of national regulatory food safety assurance programme associated with the use of veterinary drugs in food producing animals CAC/GL 71-2009 and etc. ${ }^{25}$. The organization supports risk communication systems, considers various risk management options that can be used and combined to ensure product controlling based on risks and optimizing the use of available resources.

The Eurasian Economic Union countries, in full accordance with the world tendencies, are oriented towards the application of the methodology for assessing the risk of products during control of goods safety.

The EAEU system of technical regulation and sanitary and phytosanitary measures, both in general in developed countries and in international unions, con-

\footnotetext{
${ }^{24}$ WTO Agreement on Technical Barriers to Trade. World Trade Organization. Available at: https://www.wto.org/english/docs e/legal_e/17-tbt_e.htm (25.08.2017).

${ }^{25}$ Guidelines and Standards of the Codex Alimentarius Commission. Codex Alimentarius Commission. Available at: http://www.fao.org/fao-who-codexalimentarius/codex-texts/guidelines/en/ (02.09.2017).
} 
siders product safety as the absence of unacceptable risk.

The requirements of technical regulations and uniform sanitary requirements and standards (USRS) apply to all EAEU member countries that require development of methods and criteria for risk assessment based on common principles and approaches. To help the national regulators of the EEC, a methodological document "Methodology for assessing population health risks under exposure to chemical, physical, and biological factors to determine products (goods) safety parameters" was developed [4].

However, the supranational bodies of the EAEU function somewhat differently than, for example, in the EU. For instance, the Eurasian Economic Commission (EEC), as the EAEU regulating body, has the authority to develop EAEU policy in the field of product safety, but in comparison with the EU Commission, it has less control functions at the supranational level. Thus, EEC has no right to formally explain or interpret the regulations of the Union. The Commission does not play a decisive role in trade disputes arising between the EAEU member states, or between the EAEU and any third country. It has an extremely limited capacity for supervising the mandatory execution of the EAEU regulatory acts in the territory of the member states, including in particular the sanitary measures and technical regulation (for example, the control and surveillance and arbitration functions, the right to introduce quarantine, prohibitions and restrictions in trade, temporary SPS measures with regard to third parties). The EAEU also does not assume functioning of its own bodies and institutions for inspections, conformity assessment and risk assessment.

According to a number of researchers from WHO FAO, the absence of a centralized system for managing consumer product safety and general rules for national control systems in the EAEU results in decreasing safety assurance [8].

The product safety control functions are fully implemented at the national level. At the same time, as noted above, the riskoriented approach is enshrined in all EAEU member countries. At the same time, an analysis of the regulatory framework has shown that the risk-oriented model is formed and functions in terms of classification (categorization) of the risk of harm to the health of legal entities (LE), individual entrepreneurs (IE), or their types of activities.

For example, in Russian Federation, the risk-based surveillance is regulated by the Art. 8.1. of the Federal Law No. 294-FZ of December 26, 2008 "On Protection of Rights of Legal Entities and Individual Entrepreneurs in performing State Control (Surveillance) and Municipal Control" ${ }^{26}$. At the same time, "... a risk-oriented approach is a method of organization and implementation of state control (surveillance), in which the choice of intensity (form, duration, periodicity) of control measures, measures to prevent violation in mandatory requirements is determined by referring the activities of a legal entity, individual entrepreneur and (or) production facilities they use in performing such activity to a certain risk category or a certain class

\footnotetext{
${ }^{26}$ On Protection of Rights of Legal Entities and Individual Entrepreneurs in performing State Control (Surveillance) and Municipal Control: Federal Law No. 294-FZ of 26.12.2008 Available at: http://www.consultant.ru/document/cons_doc_LAW_83079/58672404e5897f38d20be06de33c4570c75d2897/ (07.09.2017).
} 
(category) of hazard". Depending on the activity category, as per risk of harm to health, the frequency of the planned control measures varies from once a year to once in seven years and less frequently.

In 2016, the Law of the Republic of Belarus "On Sanitary and Epidemiological Wellbeing of the Population" ${ }^{27}$ was amended to legislate the application of the risk-oriented approach while ensuring the sanitary and epidemiological wellbeing of the population, inter alia, at state sanitary and epidemiological regulation and state sanitary surveillance.

In the development of these changes, the Decisions of the Ministry of Health of the Republic of Belarus No. 8 ddt. January 20, 2017 "On Approval of the Instruction on the Procedure for Risk Analysis" were adopted $^{28}$, which determines the procedure for conducting risk analysis for the planning, organization and implementation of activities on ensuring sanitary and epidemiologic wellbeing of the population.

The document legislatively establishes three interrelated elements of risk analysis (risk assessment, risk management and risk communication), which meets international requirements, defines the competence of bodies and institutions that effect state sanitary surveillance, medical scientific organizations in implementation of risk analysis.

The document sets forth the procedure for assessing risks, managing risks and informing about the risks that are being performed by the authorized institutions, including collection and studying the neces- sary publicly available information; identification (detection) of the probability of adverse effects on human organism due to habitat factors, violations of legislation in the field of sanitary and epidemiological wellbeing of the population and the consequences of this exposure, leading to a threat to life and health of the population; an assessment of acceptability of the identified (detected) risks; justification, development and selection of optimal sanitary and anti-epidemic measures, adoption and implementation of the necessary measures to prevent and minimize risks; assessment of effectiveness and adjustment (if necessary) of the measures taken; monitoring risk levels; informing the involved parties about the risks, and risk management.

The risk-oriented approach to classifying the audited entities is enshrined in the Republic of Belarus by the Decree of the President of the Republic of Belarus No. 510 of October 16, 2009 "On improving control (surveillance) in the Republic of Belarus", which was modified significantly in October $2016^{29}$. The mentioned document specifies that a random audit is appointed taking into account the criteria for assessing risk level for the selection of the audited entities, and based on the analysis of the available information in hands of the surveillance authority that indicates a high risk of violations in the law and inability to detect and (or) eliminate them using other forms of state control (surveillance). The methodology for developing risk assessment system for the audited entities is be-

\footnotetext{
${ }^{27}$ On Sanitary and Epidemiological Wellbeing of the Population: the Law of the Republic of Belarus No.340-3 of January, 7, 2012 (in wording of 30.06.2016). Available at: http://www.pravo.by/main.aspx?guid=3961\&p0=C21600205 (07.09.2017).

${ }^{28}$ On Approval of the Instruction on the Procedure for Risk Analysis: the Decisions of the Ministry of Health of the Republic of Belarus No. 8 of January, 20 2017. Available at: http://www.pravo.by/document/?guid=12551\&p0=W21731770\&p1=1 (07.09.2017).

${ }^{29}$ On improving control (surveillance) in the Republic of Belarus: the Decree of the President of the Republic of Belarus of 16.10 .2009 No.510. Available at: http://president.gov.by/ru/official documents ru/view/ ukaz-376-ot-16-oktjabrja-2017-g-17324/ (07.09.2017).
} 
ing currently elaborated.

State control and surveillance in the Republic of Kazakhstan is performed in accordance with the Code of the Republic of Kazakhstan No. 375-V of October 29, 2015 "The Entrepreneurship Code of the Republic of Kazakhstan" ${ }^{30}$ (Chapter 13). Under the Article 141, the audited subjects (objects) are allocated by groups. The state control and surveillance takes into account the distribution of the audited entities into four groups.

In the context of ensuring sanitary and epidemiological wellbeing, risk assessment is performed taking into account the frequency and "violence degree" or "significance" of the violation in mandatory requirements. At the same time, the "extreme violence" refer to "... deliberate or reckless obvious and significant violations in the legislation of the Republic of Kazakhstan in the sphere of sanitary and epidemiological wellbeing of the population whose noncompliance has entailed and (or) may entail grave consequences for the population health", to "insignificant" - "violations in the requirements of the legislation of the Republic of Kazakhstan in the field of sanitary and epidemiological wellbeing of the population, the non-compliance of which entailed and (or) may entail the formally admitted, but not inflicted any tangible harm to the population". Other violations are considered "significant".

The categorization of products by risk level is not set forth legally.

In the Republic of Armenia, according to the latest version of the Law of the
Republic of Armenia "On Organizing and Conducting Audits in the Republic of Armenia" $^{131}$, all inspection bodies should implement risk-based audit systems and plan audits taking into account business entities risks levels (high risk level: once a year, average level of risk: less frequently than once in three years, and with a low risk level: no more than once every five years).

In the Kyrgyz Republic, all entities of entrepreneurship subject to audit, taking into account the magnitude of risk, fall into one of the three risk levels: high, medium, and insignificant. The assessment of the entity's compliance with the requirements of legislation is determined by applying the checklists in which questions are grouped according to the requirements therein:

"A"group: issues that contain requirements, the failure thereof directly causes/poses an immediate threat to human life and health safety;

"B" group: issues that contain requirements, the failure thereof does not create directly an immediate threat to human life and health safety.

The differentiated criteria have been developed for further risk assessment of the operations in various types of food products, the production and distribution of veterinary preparations, the harvesting, storage and marketing of feeds and feed additives (an example is given in Table 2).

Violations are given scores that are summed up. By the scores grand total, the audited subjects are classified to high, medium or insignificant risk groups.

\footnotetext{
${ }^{30}$ The Entrepreneurship Code of the Republic of Kazakhstan (as amended on 03.07.2017). Available at: http://online.zakon.kz/Document/?doc id=38259854 (07.09.2017).

${ }^{31}$ On Organizing and Conducting Audits in the Republic of Armenia: the Law of the Republic of Armenia of 17.05.2000 (as revised on 01.03.2017). Available at: http://www.parliament.am/legislation.php?sel=show\&ID= 1364\&lang=rus (07.09.2017).
} 
Table 2

Criteria for risk assessment in the production of milk and dairy products

\begin{tabular}{|c|c|c|}
\hline $\begin{array}{l}\text { Types } \\
\text { of violations }\end{array}$ & Criterion & $\begin{array}{l}\text { The number of identified } \\
\text { non-conformities to the } \\
\text { parameters contained } \\
\text { in checklists }\end{array}$ \\
\hline \multirow[t]{4}{*}{ Extreme } & Requirements for safety of milk and dairy products in their sales & 2 and more \\
\hline & $\begin{array}{l}\text { Requirements for safety of raw materials used for the production } \\
\text { (manufacture) of milk and dairy products }\end{array}$ & 6 and more \\
\hline & Requirements for safety of starter cultures and probiotic cultures & 2 and more \\
\hline & $\begin{array}{l}\text { Requirements for safety of milk and dairy products in their produc- } \\
\text { tion (manufacture) }\end{array}$ & 9 and more \\
\hline \multirow[t]{4}{*}{ Significant } & Requirements for safety of finished dairy products & 5 and more \\
\hline & $\begin{array}{l}\text { Requirements for safety of buildings, structures used in the produc- } \\
\text { tion (manufacture) of milk and dairy products }\end{array}$ & 4 and more \\
\hline & $\begin{array}{l}\text { Requirements for safety of milk and dairy products during storage } \\
\text { and transportation }\end{array}$ & 4 and more \\
\hline & Requirements for safety of milk and dairy products for disposal & 1 and more \\
\hline Insignificant & $\begin{array}{l}\text { Requirements for safety of packaging (tare) and labeling of milk } \\
\text { and dairy products }\end{array}$ & 3 and more \\
\hline
\end{tabular}

The categorization of products by the risk of harm to health is not in place.

In 2016, the Russian Federation Chief State Sanitary Doctor approved methodological guidelines "Classification of food products traded on the market by the risk of harm to consumers' health for the organization of routine control and surveillance activities" 32 . The document is designed to classify a particular type of product to one or another class for the risk of harm to health. The risk class (category) allows justifying the selection of priority products that must be audited during control and surveillance activities at storage facilities, food transportation, food trade and catering, as well as the frequency and scope of laboratory support for audits.

The potential risk of harm $(R)$ is considered as a consequence of violations in the requirements and standards established for certain types of food products by sanitary legislation and technical regulations, and is defined as the combination of violation probability in legal requirements for food safety, the severity of health damage due to consuming the unsafe food products, and the scope of potential consumption of these products:

$$
R=\sum_{i}\left(p_{i} u_{i}\right) W,
$$

where $p_{i}$ is the probability of violations of mandatory safety requirements for food products by the $i$-criterion (factor) during one inspection. As a hazard factor, we consider all the chemicals, microbiologicalparasitic agents, radiological indices, genetically modified organisms in products examined during the control and surveillance activities;

\footnotetext{
${ }^{32}$ On the Introduction of the Methodological Guidelines "Classification of food products traded on the market by the risk of harm to consumers' health for the organization of routine control and surveillance activities": Order of the Head of the Federal Service for Surveillance on Consumers Rights Protection and Human Wellbeing No. 16 of 18.01.2016. 2016, 34 p. Available at: http://rospotrebnadzor.ru/documents/details.php?ELEMENT_ID=5672 (07.09.2017)
} 
$u_{i}:$ relative harm to health, formed by violation of safety requirements to the $i$-th factor in a given product;

$W$ is a coefficient, characterizing regional features of food products consumption.

For each type of food product, the hazard identification (chemical, microbiological, parasitological, radiation) is done, probable types of health disorders that may occur in realization of these hazards is established. For each type of product, the relative harm to health associated with the violation of $i$-th factor is calculated as the sum of the regression coefficients weighted by the severity of diseases or death. The severity of diseases is assessed using WHO criteria.

For today it is the only methodical document in the countries of the EAEU, which allows classify products according to the risk parameters for consumer health. Approaches are universal, however, the calculations based on this methodology are performed only for Russia, since data on the frequency of violations and cases of harm to consumers' health are processed following the results of control and surveillance activities in Russian Federation over the past few years.

Conclusions. The analysis has shown that the experience of the European Union, the USA and Canada can and should be used for the tasks of improving the safety control systems for mutually supplied products traded on the consumer market of the Eurasian Economic Union.

The EAEU member states are committed to the ideas of risk-oriented surveillance and set it forth in supranational and national legislation. This situation can be considered as a favorable platform for developing a system of coordinated, mutually beneficial actions on products risk-oriented surveillance. Such a system would make it possi- ble to raise interstate relations to a new, substantially more trusting objective level, to actually put up barriers to products hazardous to public health, and to minimize administrative barriers for products that do not form serious risks to consumers' health losses in the entire unified economic space of the union.

The EAEU through a sufficiently deep and wide base of the sanitaryepidemiological requirements, standards, norms, enshrined in the technical regulations, provides a criterial background for product safety. The documents are oriented to assessing the health risk, which fully corresponds to the current trends. At the same time, the system of standards and norms is constantly being improved, also thanks to the initiative of all the stakeholders. At the same time, there are no uniform approaches to categorizing products by the potential risk of harming consumer health, which complicates the interaction of the parties in bringing the audits of goods entering the common market as a result of mutual trade.

Being the body responsible for the safety of consumer products in the EAEU, the EEC has a number of powers, including the development of the EAEU policy in this area. However, the basic legal and institutional problem is the lack of legislative formalization of an independent supranational control or monitoring over the mandatory observance of the EAEU regulatory acts on the territory of the member states. No powers formalized, which could be assigned to a supranational body to perform surveillance and arbitration functions, restrictions and bans on trade, temporary sanitary measures in respect of the third parties. As a consequence, all the ambiguous, sometimes conflict situations are resolved, as a rule, bilaterally between the EAEU member states. 
The all-union information and analytical base for the assessment of products risks to consumer health requires substantial development. The creation of a publicly accessible and transparent database to contain results of state control, surveillance and monitoring of products, and also cases of causing harm to health is a topical issue. It is advisable to improve the system of informational interaction on the history of state audits of goods in the event of damage to the health of consumers, complaints about certain types of products and goods.

Analysis of the statistics data on the state surveillance regarding product safety in Russia showed that approaches to the classification of consumer products, based on the principles of risk assessment as a combination of the probability of violation in mandatory sanitary requirements for products, the probability and severity of the consequences of these violations (taking into account the scopes of products consumption) can be replicated to the Eurasian Union as a whole. This will make it possible to create "risk profiles" for certain groups of goods and allocate products that can be characterized as "risky." The classification will allow controlling in a direct, targeted manner already at the first stages of introducing the risk-oriented surveillance.

The methodology of classifying products, as well as the model of risk-based surveillance, can function effectively if all its structural elements are present:

- the information surveillance base, which is a formalized, verified and structured data on the parameters of the products being audited; on the cases of violations in the mandatory requirements for products; on the consequences of these violations; on the evidence of the relation of health disorders with the product hazard factors;
- methodical, mathematical apparatus and software tools that allow information arrays processing: to obtain simple statistics on the results of control and surveillance activities (calculation of the frequency of violations in general, by types of products, factors, manufacturers, etc.), and also to perform more knowledge-intensive operations, i.e. to establish dependencies in the system "production - harm to human health"; "measures for risk management - a characteristic of product risk"; to estimate the average and maximum expected severity of health disorders, etc .;

- the organizational structure provided by trained personnel, whose functions include collecting, processing, analyzing data and informing all interested parties about the results;

- the established channels of information exchange, whereby some participants in the process transfer primary data to the system (control results, including laboratory research protocols, data on injuries, poisoning, diseases, complaints about products, etc.), and others, as a feedback, "announce" hazard or risk assessment results for any product. It is assumed that informing about risks should be gradually transformed into a more perfect form of data exchange - risk communication.

Realizing the potential for making any meaningful decisions within the framework of the Eurasian Union solely on the basis of consensus and political will of each individual state, one cannot fail to take into account that the optimal model for interaction between states and the internal strengthening of the union is the mutual movement towards an equal and mutually beneficial partnership. Such movement should be accompanied by an increase in mutual trust, including also by following the same principles in realizing the most important powers of states at the national level. 
In this regard, in order to increase effectiveness of measures to ensure the safety of products circulated in the single economic space of the EAEU (and risk-based surveillance is such a measure), in terms of improving the legislation of the Union, one could consider the issues of normative formalization at the EAEU level of the principles for organizing product safety control common for all member countries with further implementation of these principles into national legislation.

In such a situation, methodological guidelines on the risk-based surveillance, developed on the principles agreed upon by all parties, would have a much greater demand.

In the long term, taking into account the experience of the European Union, the EAEU can consider the possibility of creating a system of supranational independent audit, taking the advantages thereof will allow arbitration, objective resolution of two or multilateral conflicts arising in products circulation and surveillance, and at the same time will ensure the increasing authority of the EAEU as a coordinating body.

To ensure broad informational interaction between the stakeholders, it seems advisable to create a single information base on the background of the national product safety control systems, to accumulate a "history" of violations, create a bank of products risk "profiles" in terms of Customs Commodity Codes, risk factors, technologies and producing countries, at a later stages - manufacturing entities. It is assumed that the system will be created in the EAEU in the short term.

In order to continuously improve product risk management system, the annual analytical reports integrated in the framework of the EAEU, based on the results of state product safety surveillance, could be of doubtless interest, with issuing relevant guidelines to the authorized national bodies and setting tasks to scientific organizations.

\section{References}

1. Arnautov O.V. O sovershenstvovanii mekhanizmov ustanovleniya i izmeneniya pokazatelei kachestva i bezopasnosti pishchevoi produktsii v normativnykh i pravovykh aktakh Evraziiskogo Ekonomicheskogo Soyuza [On improvement of the mechanism for establishing and changing indicators of quality and food safety in the regulatory and legal acts of the Eurasian Economical Union]. Voprosy pitaniya, 2016, vol. 85, no. 1, pp. 110116 (in Russian).

2. Kuchinskaya L.V. Opyt kontrolya i nadzora za potrebitel'skim rynkom stran-uchastnits Evropeiskogo soyuza [Consumer market control and monitoring experience gained by eu countries]. Vestnik Rossiiskoi tamozhennoi akademii, 2010, no. 3, pp. 38-45 (in Russian).

3. Litvinova O.S. Bezopasnost' pishchevoi produktsii v Rossiiskoi Federatsii: retrospektivnyi analiz, perspektivy kontrolya na osnove risk-orientirovannogo podkhoda [Food safety in the russian federation. retrospective analysis, the prospects of control]. Zdorov'e naseleniya i sreda obitaniya, 2016, no. 10, pp. 32-35 (in Russian).

4. Metodologiya otsenki riskov zdorov'yu naseleniya pri vozdeistvii khimicheskikh, fizicheskikh i biologicheskikh faktorov dlya opredeleniya pokazatelei bezopasnosti produktsii (tovarov) [Methodology for assessing population health risks under exposure to chemical, physical, and biological factors to determine products (goods) safety parameters]. Moscow, Yumanite media, Publ., 2014, 120 p. (in Russian).

5. Murzashev M.N., Kozhogulova G.A. Epidemiologicheskaya situatsiya po pishchevym otravleniyam, v tom chisle po botulizmu v g. Bishkek [Epidemiological situation on food poisoning, including botulism in Bishkek]. Zdravookhranenie Kyrgyzstana, 2016, no. 3, pp. 38-40 (in Russian).

6. O sostoyanii sanitarno-epidemiologicheskogo blagopoluchiya naseleniya v Zabaikal'skom krae v 2016 godu: Doklad [On sanitary and epidemiologic welfare of the population in Zabaikalsk region in 2016: Report]. Upravlenie Federal'noi sluzhby po nadzoru v sfere zashchity prav potrebitelei i blagopoluchiya cheloveka po Zabaikal'skomu krayu, 2017, 224 p. (in Russian). 
7. Ryzhkov V.V., Kolupaev V.V., Efremov A.Yu. Issledovanie kharakternykh sluchaev pishchevykh otravlenii v molodezhnoi srede [Examination of typical food intoxications among young people]. Formirovanie issledovatel'skikh kompetentsii lichnosti didakticheskimi sredstvami: materialy nauch.-prakt. studench. konf. (Voronezh, 20 apr. 2017 g.) [Developing research competences of a person via didactic techniques: materials of theoretical and practical students' conference (Voronezh, 20 April 2017 2.)]. In: A.Yu. Efremov, I.F. Berezhnaya, M.D. Kniga, eds. Cheboksary, TsNS «Interaktiv plyus», Publ., 2017, pp. 177-180 (in Russian).

8. Sedik D., Ul'brikht K., Dzhamankulov N. Sistema kontrolya bezopasnosti pishchevoi produktsii v Evropeiskom Soyuze i Evraziiskom ekonomicheskom soyuze [Control system food safety in the European Union and the Eurasian Economic Union]. Torgovaya politika, 2016, no. 2 (6), pp. 41-83 (in Russian).

9. Fedorenko E.V. Pravovye osnovy primeneniya metodologii analiza riska pri obespechenii bezopasnosti pishchevoi produktsii v Evraziiskom ekonomicheskom soyuze i Respublike Belarus' [Legal basis for risk analysis methodology while ensuring food safety in the Eurasian Economic union and the Republic of Belarus]. Health Risk Analysis, 2015, no. 3, pp. 13-18. DOI: 10.21668/health.risk/2015.3.02.eng

10. Fokin V.A. Identifikatsiya opasnosti s posleduyushchim provedeniem otsenki riska ostatochnykh kolichestv kadmiya v pishchevoi produktsii kak faktora riska razvitiya negativnykh effektov na zdorov'e cheloveka [Hazard identification, followed by risk assessment of residues of cadmium in food as a risk factor for adverse effects on human health]. Sanitarnyi vrach, 2015, no. 10, pp. 63-67 (in Russian).

11. Formirovanie Evraziiskogo Ekonomicheskogo Soyuza: riski i shansy. Ezhegodnyi doklad Integratsionnogo kluba pri Predsedatele Soveta Federatsii Federal'nogo Sobraniya RF za 2014 god [Creation of the Eurasian Economic Union: risks and opportunities. The annual report by the Integration club supervised by the Chairman of the Federal Council, the RF Federal Assembly, 2014]. Moscow, Izdanie Soveta Federatsii, Publ., 2015,95 p. (in Russian).

12. Solodovnikov Yu.P., Gladkikh A.M., Shusherina T.F., Andreeva I.V., Tibekin A.T., Lytkina I.N., Ermolenko M.V. Epidemicheskaya vspyshka pishchevogo otravleniya vo vremya svad"by (chast' 1) [An epidemic outbreak of food poisoning during the wedding (part 1)]. Zhurnal mikrobiologii, epidemiologii i immunobiologii, 2005, no. 1, pp. 111-112.

13. Eriksson J., Öborn I., Olsson I.-M., Oskarsson A., Skerfving S., Eriksson J. Cadmium in food production systems: a health risk for sensitive population groups. Ambio, 2005, vol. 34, no. 4-5, pp. 344-351.

14. Phillips Ia., Casewell M., Cox T., De Groot B., Friis Ch., Jones R., Nightingale Ch., Preston R., Waddell J. Does the use of antibiotics in food pose a risk to human health? A critical review of publishing data. Journal of Antimicrobial Chemotherapy, 2004, vol. 53, no. 1, pp. 28.

15. FAO Risk based imported food control. Rome. 2016. Available at: http://www.fao.org/3/a-i5381e.pdf (07.08.2017).

16. General Use Products: Certification and Testing / United States Consumer Product Safety Comission. Business \& Manufacturing. Testing Certification. Available at: https://www.cpsc.gov/Business--Manufacturing/TestingCertification/General-Use-Products-Certification-and-Testing/ (07.08.2017).

17. Guidance for risk assessment of food and feed from genetically modified plants. EFSA Journal, 2011, no. 9 , pp. 2150 .

18. New Legislative Framework. European Commission: Single Market for Goods. Available at: https:// ec.europa.eu/growth/single-market/goods/new-legislative-framework_en (07.08.2017).

19. Overview Reports. European Commission: Food. Health and Food audits and analysis. Available at: http://ec.europa.eu/food/audits-analysis/overview reports/index.cfm (07.08.2017).

20. Port Surveillance News: CPSC Uses Pilot Risk Assessment Tool to Strengthen Import Safety Program. CPSC.gov is the U.S. government's official web portal, 2013. Available at: https://www.cpsc.gov/newsroom/newsreleases/2014/cpsc-uses-pilot-risk-assessment-tool-to-strengthen-import-safety (07.08.2017).

21. Snyder v. Am. Ass'n of Blood Banks, 144 N.J. 269 (N.J. June 4, 1996). Available at: https://www.casebriefs.com/blog/law/torts/torts-keyed-to-dobbs/the-duty-to-protect-from-third-persons/snyder-v-american-association-of-blood-banks (07.08.2017).

Zaitseva N.V., May I.V., Sychik S.I., Fedorenko E.V., Shevchuk L.M. Analysis of legal and methodological grounds for risk-oriented surveillance over consumer products: tasks and development prospects in the Eurasian Economic Union. Health Risk Analysis, 2017, no. 4, pp. 4-22. DOI: 10.21668/health.risk/2017.4.01.eng

Received: 08.09.2017

Accepted: 15.12.2017

Published: 30.12 .2017 